\title{
A new hairy Leptogium (section Mallotium) from Rio Grande do Sul State, Brazil
}

\author{
Marcos Junji Kitaura ${ }^{1,4}$, Márcia Isabel Käffer ${ }^{2}$, Marcelo Pinto Marcelli ${ }^{3}$ and \\ Suzana Maria de Azevedo Martins ${ }^{2}$
}

Received: 6.09.2013; accepted: 22.01.2014

\begin{abstract}
A new hairy Leptogium (section Mallotium) from Rio Grande do Sul State, Brazil). The hairs of Leptogium species are complex structures which determine taxonomic groups within the section Mallotium. The hairs composed of cylindrical cells can be short and, when present on the surface, give origin to glass-or velvet-like hairs. Leptogium involutum, collected in Southern Brazil, a new species with velvet-like hairs is described herewith.
\end{abstract}

Keywords: cylindrical cells, involute margin, Leptogium velutinum

RESUMO - (Uma nova espécie de Leptogium com pêlos (seção Mallotium) do Estado do Rio Grande do Sul, Brasil). Os pêlos das espécies de Leptogium são estruturas complexas que podem determinar grupos dentro da seção Mallotium. Os pêlos compostos de células cilíndricas podem ser curtos e, quando presentes oferecem a superfície uma aparência brilhante (como vidro) ou aveludada. Leptogium involutum, coletada na região Sul do Brasil, uma espécie nova com pêlos aveludados é descrita aqui.

Palavras-chave: células cilíndricas, Leptogium velutinum, margem involuta

\section{Introduction}

Leptogium species with hairs on one or both surfaces of the thallus have traditionally been grouped into section Mallotium (Ach.) Vain. (Vainio 1890, Sierk 1964, Awasthi \& Akhtar 1977). The hairs are complex structures and they have morphological and anatomical characteristics which have been used to delineate species (Jørgensen 1997).

Such hairs can be composed of either spherical or cylindrical cells (Jørgensen 1973, Swinscow \& Krog 1988). The spherical cells form short hairs which are up to $25 \mu \mathrm{m}$ long, whereas the cylindrical cells generally form longer hairs which are up to $100 \mu \mathrm{m}$ long and are called beard-like (Jørgensen 1997).

Nevertheless, three species with cylindrical cells form hairs with less than $50 \mu \mathrm{m}$ long and were denominated glass-or velvet-like hairs (Jørgensen 1997): Leptogium australe (Hook. f. \& Taylor) Müll. Arg. that was originally collected in Cape Horn, Chile and L. puberulum Hue which is an Antarctic species, both have glass-like hairs; and L. velutinum P.M. Jørg., which is from the Andes of Ecuador and is the only species known with velvet-like hairs (Jørgensen 1997).

The present work describes a new species of Leptogium with velvet-like hairs that was collected in Rio Grande do Sul State, Brazil. Our research was aimed at giving high accuracy to descriptions of supposedly well-known Leptogium species (Kitaura 2012, Kitaura \& Marcelli 2013, Kitaura et al. 2013). Furthermore, we also worked on the type material of Leptogium velutinum. Herewith we present the results of this study, which are relevant to the description of the new species.

\section{Materials and methods}

The material has been collected from Santana do Livramento Municipality, Rio Grande do Sul State, Brazil and it does not have apothecial structure.

1. Universidade Estadual Paulista “Júlio de Mesquita Filho”, Instituto de Biociências, Departamento de Botânica, Distrito de Rubião Jr., Caixa Postal 510, 18618-970 Botucatu, SP, Brasil

2. Fundação Zoobotânica do Rio Grande do Sul, Museu de Ciências Naturais, Caixa Postal 1188, 90001-970 Porto Alegre, RS, Brasil.

3. Instituto de Botânica, Núcleo de Pesquisa em Micologia, Caixa Postal 68041, 04045-972 São Paulo,SP, Brasil

4. Corresponding author: junjimjk@gmail.com 
The holotype and isotype specimens of Leptogium velutinum were generously loaned from GB herbarium.

All specimens were described following the protocol of Kitaura (2012) and the anatomical structures are mentioned following Kitaura \& Marcelli (2013) as well as Kitaura et al. (2013).

\section{Results and Discussion}

The glass-or velvet-like hairs have an appearance similar to those hairs made of spherical cells (e.g. Leptogium burgessii (L.) Mont., L. digitatum (A. Massal.) Zahlbr., L. hibernicum M.E. Mitch. ex P.M. Jørg. and L. laceroides B. de Lesd.), when observed at naked eye. The hairs usually are up to $50 \mu \mathrm{m}$ long and usually do not form agglutinated structure just like the bread-like hair group. Therefore, further anatomical studies are necessary to analyze the cells of the hairs and to delineate the species.

Leptogium velutinum P.M. Jørg., Symbolae Botanicae Upsalienses 32: 124. 1997. ECUADOR. Morona-Santiago: Road Gualaceo-General Plaza (Limon), eastern slopes of eastern Cordillera, 2600m, cloud forest, 10-II-1979, leg. L. Arvidsson \& D. Nilson 1767 (holotype and isotype: GB!).

Figures 1-2

Thallus ca. $10 \mathrm{~cm}$ broad, light gray to beige (hairs) with brownish margins of lobes under fluorescent light (naked eye), opaque, matt, light gray with dark brown to blackish margin of lobes under stereomicroscope. Lobes 3-10 mm wide, slightly overlapping, attached in points, adnate and concave, upper surface smooth to the naked eye, rugulose with some depressions under $20 \times$ magnification; apices rotund, flatted to involute, smooth; lateral margin smooth, ascending, undulated; lower side beige velvety, pubescent when observed with different magnifications. Isidia absent. Lobuloid structures flattened, rotund, simple, ca. $0.75 \times 0.75 \mathrm{~mm}$, laminal and on the margin of apothecia, rare. Thallus attached by hairs; hairs usually simple, ca. $50 \mu \mathrm{m}$ long, beige, on the lower side and on upper surface around of apothecia, densely (velvety), short cylindrical cells but not spherical, 6-8 cells long; hapterons and rhizines absent. Apothecia to $3.5 \mathrm{~mm}$ diam., laminal, concave; margin brownish, smooth, without ornamentation or with granular to irregular lobuloid structures; amphithecia brown to beige, pubescent, with or without lobuloid structures, hairs non agglutinated; corona discontinuous, slightly evident, only on young apothecium, old apothecium with lobuloid or nodular structures; pedicel thalline to $1 \mathrm{~mm}$ long, smooth, pubescent.
Thallus $50-55 \mu \mathrm{m}$ thick, quadratic cells of upper cortex 5.0-10.0 $\times$ 5.0-7.5 $\mu \mathrm{m}$, quadratic cells of lower cortex 7.5-12.5 × 5.0-7.5 $\mu \mathrm{m}$; columnar hyphae 2.5-7.5 $\mu \mathrm{m}$ thick, straight to slightly inclined, 2-4 cells, simple. Cyanobacteria green or blue, scarce to frequent, ca. 7 spherical cells by filament, ca. $2.5 \mu \mathrm{m}$ diam.; matrix gelatinous scarce, hyaline and yellow next to the upper cortex. Apothecia with hymenia 200-225 $\mu \mathrm{m}$ high, subhymenia 40-50 $\mu \mathrm{m}$ thick, hyaline to slightly yellow; hypothecia 55-65 $\mu \mathrm{m}$ thick, proso-to colloplectenchymatous cells; subhymenial paraplectenchymatous tissue absent; parahymenial tissue continuous with hypothecium, as higher as hymenium, 10-15 $\mu \mathrm{m}$ (ca. 5 cells) thick at base, 20-25 $\mu \mathrm{m}$ (ca. 5 cells) thick at apex, colloplectenchymatous to paraplectenchymatous cells; amphithecia up to $7 / 8$ of hymenium height, 120-140 $\mu \mathrm{m}$ (10-12 cells) thick at apex, 190-200 (8-10 cells) thick at mid-height, $250-270 \mu \mathrm{m}$ (12-15 cells) thick at base; tunnels plenty of photobiont cells usually present on the margin; basal paraplectenchymatous cells beige (pubescent color), 160-180 $\mu \mathrm{m}$ (10-15 cells) thick. Ascospores fusiform, 30-55 × 15-20 $\mu \mathrm{m}$, 6-7 $\times 3-4$ cells, apices acute to obtuse, muriform. Pycnidia laminal to submarginal, usually blackish. Conidia bifusiform or bacillary, $3.75 \times 1.25 \mu \mathrm{m}$.

Leptogium velutinum is characterized by upper surface smooth, a velvety lower side, and the thalline stipe elevating the apothecia, which have corona originating either nodular or lobuloid structures. The amphithecia have tunnels filled by photobiont cells whose apices originate the coronal nodular or lobuloid structures.

Jørgensen (1997) suggested that Leptogium velutinum has hybrid origin between $L$. andinum and $L$. burgessii, since the hairs have isodiametric cells basally and cylindrical ones apically, however we found only hairs made of short cylindrical cells (figura 2) in our histological sections.

Leptogium involutum Kitaura, Käffer \& S.M. Martins, $s p$. nov. BRAZIL. Rio GRANDE Do SUL: Rio Grande do Sul State, Municipality of Santana do Livramento, APA do Ibirapuitã, Estância São Maurício, riparian forest in a native grassland matrix, $30^{\circ} 37^{\prime} 77.9^{\prime \prime} \mathrm{S}, 55^{\circ} 33^{\prime} 92.9^{\prime \prime} \mathrm{W}, 871 \mathrm{~m}$ of altitude, on a tree trunk, 14-XI-2012, leg. M. Käffer \& S.M. Martins 437 (holotype: HAS 89100).

Figures 3-4

Etymology: The lobes and lateral margins are involute.

Thallus ca. $10 \mathrm{~cm}$ broad, blackish under fluorescent light (naked eye), opaque, matt, dark 
gray under stereomicroscope. Lobes 1-6 mm wide, overlapping, attached in points, adnate, upper surface slightly ridged to the naked eye, irregular to longitudinal ridges under $20 \times$ magnification, hairs on the apices of the ridges; apices rotund, ascending and involute, smooth; lateral margin smooth, ascending and involute, undulated; lower side beige, naked surface dark gray, hairy to the naked eye, ridged under $20 \times$ magnification. Isidia and lobules absent. Thallus attached by hairs; hairs simple, ca. $50 \mu \mathrm{m}$ long, white to beige, frequent on upper surface on the apices of the ridges and abundant on lower surface (velvety),
4-6 cylindrical cells long, present usually on the apices of ridges; hapterons and rhizines absent. Apothecia absent.

Thallus 125-150 $\mu \mathrm{m}$ thick, 325-350 $\mu \mathrm{m}$ thick at the ridges, quadratic cells of the cortices 5.0-7.5 $\times$ 7.5-10.0 $\mu \mathrm{m}$; columnar cells absent. Cyanobacteria green, frequent, 12-23 elongated cells by filament, 2.5-5.0 $\times$ ca. $10.0 \mu \mathrm{m}$; matrix gelatinous frequent, hyaline to yellow. Pycnidia marginal, slightly brownish. Conidia bacillary, 2.5-3.75 × ca. $1.25 \mu \mathrm{m}$.

Leptogium involutum is a ridged species with margins of lobes ascending, but strongly involute. The

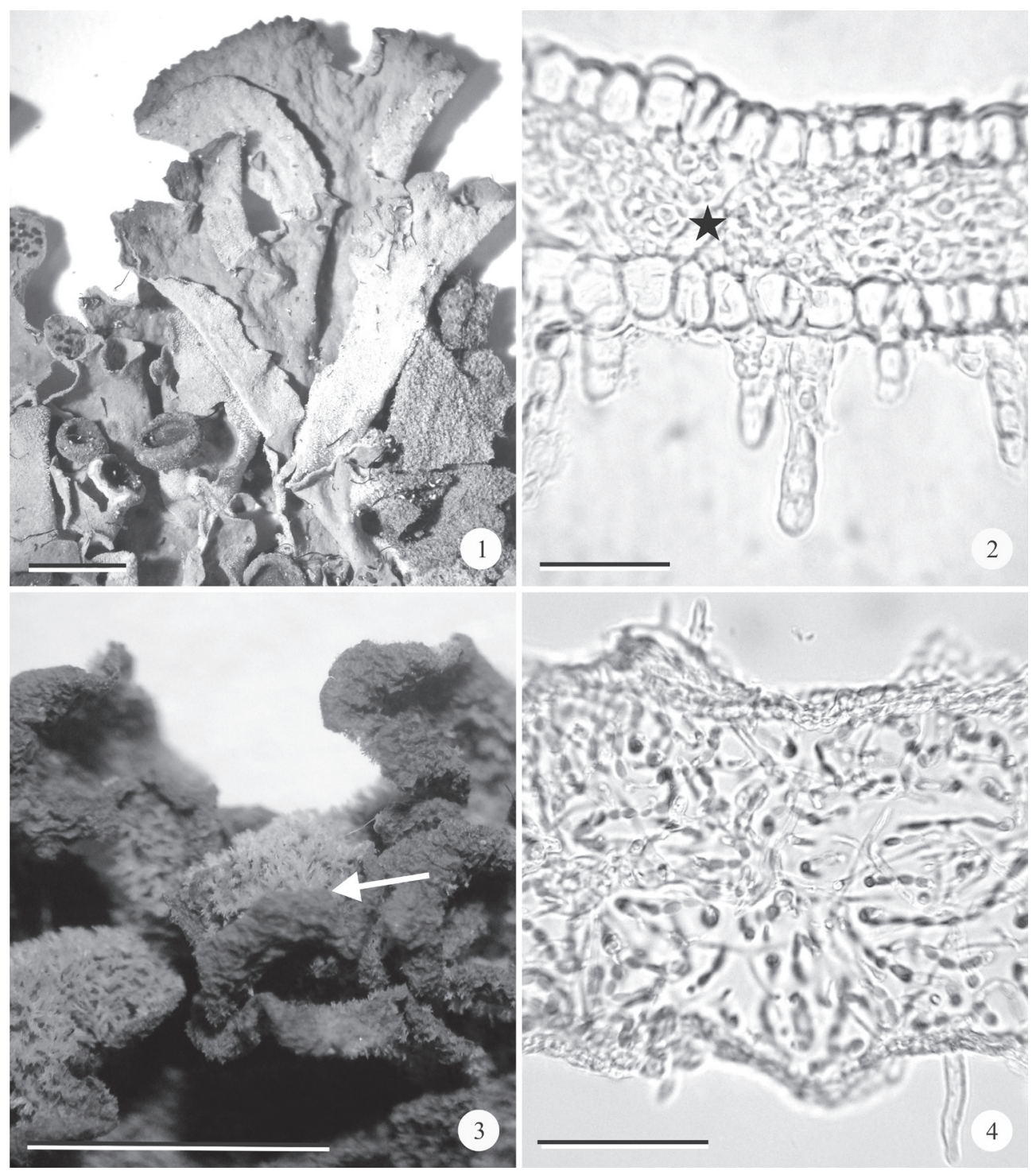

Figures 1-4. 1-2. Holotype of Leptogium velutinum. 1. Detail of thallus. 2. Transversal section of the thallus with columnar hyphae (star). 3-4. Holotype of Leptogium involutum. 3. Detail of the involute margin (arrow). 4. Transversal section of the thallus without columnar hyphae. Bars: 1 and $3=3 \mathrm{~mm} ; 2$ and $4=50 \mu \mathrm{m}$.

Figuras 1-4. 1-2. Holotipo de Leptogium velutinum. 1. Detalhe do talo. 2. Secção transversal do talo com hifas colunares (estrela). 3-4. Holotipo de Leptogium involutum. 3. Detalhe da margem (seta). 4. Secção transversal do talo sem hifas colunares. Barras: 1 and $3=3 \mathrm{~mm} ; 2$ and $4=50 \mu \mathrm{m}$. 
hairs are short (velvety), ca. $50 \mu \mathrm{m}$ long and usually on the lower cortex. The ridges of the upper surface also have hairs, but they are restricted to the apices. This species does not show columnar hyphae connecting the cortices.

Both Leptogium involutum and $L$. velutinum have a velvety lower side, but $L$. involutum has ridged surfaces and a thallus without columnar hyphae, whereas $L$. velutinum has smooth surfaces and straight to slightly inclined columnar hyphae. Whenever the columnar hyphae are present in Leptogium, the apothecium usually has a thick amphithecial tissue and lacks paraplectenchymatous subhymenial tissue; otherwise, when the thallus has not columnar hyphae, the apothecium has a one-celled amphithecial tissue and thick paraplectenchymatous subhymenial tissue (Kitaura 2012, Kitaura \& Marcelli 2013).

Leptogium australe also has hairs on both surfaces (Jørgensen 1997) as well as L. involutum, but the upper surface is smooth to undulate and the apothecium has thick amphithecial tissue (Malme 1924, Jørgensen 1975, Galloway 1999).

Leptogium puberulum, last but not least, this species with glass-like hairs, has hairs only on the lower surface and the thallus is smooth with margins often sinuous (Hue 1915), which differs from L. involutum which has hairs on both surfaces, thallus ridged and ascending, however, involute margin.

Leptogium involutum is the only species with ridged surface and short hairs composed of cylindrical cells.

Key to species with glass- and velvet-like hairs

1. Upper surface ridged Leptogium involutum

1. Upper surface without ridges (smooth, rugose, undulate, etc.)

2. Hairs on the lower side only ........... L. puberulum

2. Hairs on both surfaces

3. Thallus with glass-like hairs .......... L. australe 3b. Thallus with velvet-like hairs .... L. velutinum

\section{Acknowledgements}

The authors wish to thank Dr. Claes Persson (GB) for the loan of the types of Leptogium velutinum and also all the assessors for their valuable suggestions.
M.J. Kitaura is grateful to FAPESP for the doctoral scholarship Grant (2008/51072-3). M.P. Marcelli to $\mathrm{CNPq}$ for a research grant and M.I. Käffer to $\mathrm{CNPq}$ (160115/2012-4) for a post-doctoral fellowship, respectively.

\section{Literature cited}

Awasthi, D.D. \& Akhtar, P. 1977. The genus Leptogium (sect. Mallotium) in India. Norwegian Journal of Botany 24: 59-71.

Galloway, D.J. 1999. Notes on the lichen genus Leptogium (Collemataceae, Ascomycota) in New Zealand. Nova Hedwigia 64: 317-355.

Hue, A.M. 1915. Sciences Naturelles: Documents scientifiques. Lichens. In: J. Charcot (commandée par le). Deuxième expédition antarctique francaise (19081910). Paris, Masson, pp. 6-103.

Jørgensen, P.M. 1973. On some Leptogium species with short Mallotium hairs. Svensk Botanisk Tidskrift 67: 53-58.

Jørgensen, P.M. 1975. Contributions to a monograph of the Mallotium-hair Leptogium species. Herzogia 3: 433-460.

Jørgensen, P.M. 1997. Further notes on hairy Leptogium species. Symbolae Botanicae Upsalienses 32: 113-130.

Kitaura, M.J. 2012. Estudos taxonômicos de Leptogium (Ach.) S.F. Gray (Collemataceae, fungos liquenizados). Tese de Doutorado, Universidade Estadual Paulista, Botucatu.

Kitaura, M.J. \& Marcelli, M.P. 2012. The Leptogium juressianum complex in southeastern Brazil. Mycotaxon 120: $215-221$

Kitaura, M.J. \& Marcelli, M.P. 2013. A revision of Leptogium species with spherical-celled hairs (section Mallotium p.p.). The Bryologist 116: 15-27.

Kitaura, M.J., Marcelli, M.P., Jungbluth, P. \& Hora, B.R. 2013. Five supposedly well-known species of Leptogium section Mallotium. Mocosphere 4: 520-530.

Malme, G.O.A. 1924. Die Collematazeen dês Regnellschen Herbars. Arkiv för Botanik 19(8): 1-29.

Sierk, H.A. 1964. The genus Leptogium in North America North of Mexico. The Bryologist 67: 245-317.

Swinscow, T.D.V. \& Krog, H. 1988. Macrolichens of East Africa. British Museum (Natural History), London.

Vainio, E.A. 1890. Étude sur la classificationnaturalle et la morphologie des lichens du Brésil. Acta Societatis pro Fauna et Flora Fennica. v. 7. Helsingforsiae. 